\title{
Screening, purification and characterization of cellulase from cellulase producing bacteria in molasses
}

Farjana Islam ${ }^{1,2^{*}}$ (D) and Narayan Roy ${ }^{1}$

\begin{abstract}
Objectives: This study was conducted to isolate, screening and purification of cellulase from bacteria present in sugar industry waste (molasses) and characterization by morphological and biochemical analysis.

Results: Based on experiments, three bacterial strains produced clear transparent zone into carboxymethyl cellulose (CMC) agar plate were identified as cellulase producing bacteria. Different culture parameters such as pH, temperature, incubation period, substrate concentration and carbon sources were optimized for enzyme production. According to the morphological and biochemical tests, the isolated strains were identified as Paenibacillus sp., Bacillus sp. and Aeromonas sp. The first strain Paenibacillus sp. showed high potentiality for maximum cellulase production $\left(0.9 \mu \mathrm{mol} \mathrm{ml} \mathrm{min}^{-1}\right)$ at $\mathrm{pH} 7.0$ after $24 \mathrm{~h}$ of incubation at $40^{\circ} \mathrm{C}$ in a medium containing $1.0 \% \mathrm{CMC}$. Then Paenibacillus sp. was selected for enzyme purification by ammonium sulfate precipitation, DEAE-cellulose and CM-cellulose column chromatography, respectively. In last step of purification, specific activity, recovery and purification fold were $2655 \mathrm{U} / \mathrm{mg}, 35.7 \%$ and 9.7, respectively. The molecular weight of the purified cellulase was found to be $67 \mathrm{kDa}$ by SDS-PAGE, had an optimal $\mathrm{pH}$ and temperature at 7.0 and $40^{\circ} \mathrm{C}$. According to substrate specificity, the purified cellulase had high specificity on CMC substrate which indicated it to be an endo- $\beta-1,4-g l u c a n a s e$.
\end{abstract}

Keywords: Cellulase, Cellulose, Molasses, Bacteria, Screening, Purification and characterization

\section{Introduction}

Cellulose is a homopolymer of D-glucose units linked by $\beta-1,4$ bonds [1]. It is the most abundant biomass and a major structural component of plants and a renewable source of energy in the biosphere [2-4]. Therefore, it has become considerable economic interest to develop suitable processes for effective treatment and utilization of cellulose containing wastes as cheap carbon sources [5]. Cellulose is mainly degraded by cellulase enzyme which is commonly produced by bacteria and fungi [6]. The cellulases can effectively hydrolyze cellulose into glucose unit via the synergistic actions of the enzymes, known as endo- $\beta-1,4$ glucanase, cellobiohydrolase and $\beta$-Dglucosidase [7].

\footnotetext{
*Correspondence: farjanaislam308@gmail.com

1 Department of Biochemistry and Molecular Biology, University of Rajshahi, Rajshahi 6205, Bangladesh

Full list of author information is available at the end of the article
}

Cellulases have attracted much interest because of their diverse application in textile, detergent, leather, food, feed and paper industries $[4,8-11]$. It is also used in biomass fermentation, fiber modification and in pharmaceutical purposes $[5,12]$. Application of these enzymes in such industries demands the identification of stable enzymes that can active at high $\mathrm{pH}$ and increased temperature [9]. The growth rate of bacteria is faster than fungi and has been widely used in cellulase production under different culture conditions [13].

For many years, several studies on isolation and characterization of cellulose degrading bacteria from industrial wastes indicated that only a small number of bacteria can produces large amount of bioactive compounds that are capable of complete hydrolysis of crystalline cellulose in vitro $[2,14]$. Among different industrial wastes, sugar industry wastes such molasses are mainly cellulosic in nature and the microorganisms present there have the capacity to degrade cellulose into glucose units for their 
normal growth and development [15]. Therefore, this study was conducted to screening, optimization, purification and characterization of cellulase from cellulase producing bacteria present in molasses.

\section{Main text \\ Materials and methods \\ Isolation and screening of cellulase producing bacteria}

Molasses were collected from a sugar industry area located in Katakhali region of Rajshahi city area in Bangladesh. The collected sample $(1 \mathrm{~g})$ was led to serial dilution. The diluted sample up to $10^{-6}$ was taken into Luria-Bertani (LB) medium. Then $100 \mu \mathrm{l}$ of the solution was transferred into $1 \mathrm{l}$ of carboxymethyl cellulose (CMC) agar media plates containing $0.5 \mathrm{~g} \mathrm{KH}_{2} \mathrm{PO}_{4}, 0.25 \mathrm{~g}$ $\mathrm{MgSO}_{4}, 0.25 \mathrm{~g}$ cellulose and $2 \mathrm{~g}$ gelatin for the enhancement of the bacterial activity. The plates were then incubated at $37{ }^{\circ} \mathrm{C}$ for overnight and preserved at $4{ }^{\circ} \mathrm{C}[16]$. The enzyme activity was confirmed by different types of methods such as congo red, iodine solution and filter paper degradation method $[17,18]$. The bacterial isolates were inoculated in a basal salt medium containing filter paper for their cellulytic activity test.

\section{Identification of cellulytic bacteria by morphological and biochemical characterization \\ Morphological characterization}

The plates were examined for Gram staining and microscopic viewing for identification of bacterial strains [19]. This technique was used to distinguish the gram positive and gram negative bacteria.

\section{Biochemical characterization}

The bacterial isolates were identified by performing several biochemical tests like Fermentation test, Catalase test, Citrate utilization test, Methyl-red test, $\mathrm{H}_{2} \mathrm{~S}$ production and Voges-Proskauer test by standard methods [20].

\section{Optimization of culture conditions on cellulase activity}

To determine the effects of $\mathrm{pH}$, temperature, incubation period, substrate concentration and carbon sources on cellulase production, selected bacterial isolates were grown in CMC broth media and tested at various parameters. The effects of all factors on enzyme activity were determined by measuring the cellulase activity at different $\mathrm{pH}$ values $(5-11)$ and the temperature $\left(20-45^{\circ} \mathrm{C}\right)$ and the incubation period $(24-96 \mathrm{~h})$ at $37^{\circ} \mathrm{C}$. The various concentrations of CMC substrate $(0.5-2 \%)$ were used to get the maximum cellulase production. Carbon sources have been replaced by various substances. Applied carbon sources were xylose, oat spelt xylan, rich bran xylan, starch, carboxymethyl cellulose, cellobiose, wheat bran xylan and chitin. Different types of nitrogen sources metal salts were used to observe the effects on growth and enzyme production (data not shown).

\section{Enzyme assay Preparation of crude enzyme}

The isolate that showed a maximum zone of hydrolysis was cultured in LB broth medium and incubated at $37^{\circ} \mathrm{C}$ for overnight. Then the cultures were centrifuged and clear supernatant was used as a source of crude enzyme solution.

Endo- $\beta$-1,4-glucanase activity assay by DNS method Endo- $\beta$-1,4-glucanase activity of cellulase was measured by DNS (3,5-dinitrosalicylic acid) method through the amount of reducing sugars liberated during hydrolysis [21]. 1\% solution of CMC was prepared in $1 \mathrm{~N}$ citrate buffer ( $\mathrm{pH}$ 5.0) and was considered as substrate. $100 \mu \mathrm{l}$ crude enzymes and $1 \mathrm{ml}$ citrate buffer were added into the mixture of $1 \mathrm{ml} \mathrm{CMC}$ solution. The mixture was incubated at $45{ }^{\circ} \mathrm{C}$ for $30 \mathrm{~min}$. Then DNS was added to the solution to stop the reaction [21]. The treated samples were boiled for $10 \mathrm{~min}$, cooled in water for color stabilization and the optical density was measured at $540 \mathrm{~nm}$. One unit of endo- $\beta$-1,4-glucanase activity was defined as the amount of enzyme that could hydrolyze CMC and release $1 \mu \mathrm{mol}$ of glucose within $1 \mathrm{~min}$ of reaction [5].

\section{Purification of cellulase Ammonium sulfate precipitation}

The prepared crude enzyme was brought to $80 \%$ saturation with solid ammonium sulphate. The mixture was kept overnight at $4{ }^{\circ} \mathrm{C}$ in a magnetic stirrer. Then the mixture was centrifuged and the pellet was dissolved in $50 \mathrm{mM}$ sodium phosphate buffer saline at $\mathrm{pH} 7.0$ for further purification. The partially purified enzyme was dialyzed against the phosphate buffer.

\section{DEAE-cellulose column chromatography}

$60 \mathrm{ml}$ of the enzyme sample was applied to DEAE-cellulose (Diethylaminoethyl cellulose) column which was equilibrated with $10 \mathrm{mM}$ Tris-Hcl buffer at $\mathrm{pH}$ 7.0. The collected unbound eluted fraction was used for measuring the enzyme activity at $540 \mathrm{~nm}$ and protein concentration at $280 \mathrm{~nm}$. The fraction showing high activity was pooled and kept for SDS-PAGE (sodium dodecyl sulfate polyacrylamide gel electrophoresis) analysis.

\section{CM-cellulose column chromatography}

$55 \mathrm{ml}$ of DEAE unbound solution was applied to CM-cellulose column which was equilibrated with $10 \mathrm{mM}$ Tris$\mathrm{HCl}$ buffer at $\mathrm{pH}$ 7.0. Proteins were eluted by gradually increasing of $\mathrm{NaCl}$ gradient from 0.0 to $0.3 \mathrm{M}$ with the 
same buffer. After the enzyme activity assay, the eluted fraction was stored for SDS-PAGE analysis.

\section{Protein estimation and molecular weight determination}

Protein concentrations in the crude sample were estimated by using Lowry method with bovine serum albumin (BSA) as a standard [22] and SDS-PAGE was used for molecular weight determination [23]. The standard proteins markers were loaded next to the purified protein, followed by the crude and dialyzed sample.

\section{Determination of substrate specificity}

The various polysaccharides like carboxymethyl cellulose, xylose, oat spelt xylan, rich bran xylan, cellulose, lactose and wheat bran xylan was used to determine the substrate specificity of the purified cellulase from strain $C_{1}$ [16].

\section{Results \\ Isolation, screening and identification of cellulase producing bacteria}

The biochemical characterizations of the isolated strains $\left(\mathrm{C}_{1}, \mathrm{C}_{2}\right.$ and $\left.\mathrm{C}_{3}\right)$ are presented in Additional file 3: Supplementary Table 1 . A microscopic examination revealed that the isolated strain $C_{1}$ and $C_{2}$ was rod shaped and found to be gram positive where as $C_{3}$ strain was short rod in shape and found to be gram negative. Based on both biochemical and morphological characteristics, the isolated strains were identified to be Paenibacillus sp. $\left(C_{1}\right)$, Bacillus sp. $\left(C_{2}\right)$ and Aeromonas sp. $\left(C_{3}\right)$, respectively, where $C_{1}$ and $C_{2}$ was gram positive and $C_{3}$ was gram negative bacteria. In filter paper degradation assay, all strains were found to completely degrade the filter paper with incubation period of 7 days (Additional file 1: Supplementary Fig. 1), indicates that the isolated strains were cellulytic bacteria.

\section{Optimization of culture conditions and enzyme activity}

The optimization of culture conditions on cellulase production are presented in Fig. 1 . At neutral $\mathrm{pH}$, the $\mathrm{C}_{1}$ strain showed highest enzyme activity $\left(0.90 \mu \mathrm{mol} \mathrm{ml}^{-1}\right.$ $\mathrm{min}^{-1}$ ) at $40{ }^{\circ} \mathrm{C}$. The $\mathrm{C}_{1}$ isolate produced maximum amount of cellulase and showed highest enzyme activity $\left(0.98\right.$ and $\left.0.97 \mu \mathrm{mol} \mathrm{ml}{ }^{-1} \mathrm{~min}^{-1}\right)$ on $24 \mathrm{~h}$ incubation period at $1 \% \mathrm{CMC}$ concentration, respectively. Among different carbon sources, CMC was found to be the most suitable one for the organism growth as well as better cellulase production. Peptone as a nitrogen sources and $\mathrm{CaCl}_{2}$ as a metal salt showed the profound effect on cellulase production (data not shown).

\section{Purification of cellulase}

Details for the cellulase purification are presented in Table 1 . The crude enzyme extract contained $300 \mathrm{mg}$ protein showed 81,788 U/l in terms of total activity. In the final stage of purification with CMC column chromatography, the specific activity, yield and purification fold were $2655 \mathrm{U} / \mathrm{mg}, 35.7 \%$ and 9.7 , respectively.

\section{Molecular weight determination}

The molecular weight of the enzyme was found to be $67 \mathrm{kDa}$ comparing with the marker proteins (Fig. 2).

\section{Substrate specificity}

The purified cellulase from strain $C_{1}$ showed the highest activity against CMC and low activity to wheat bran xylan, lactose, rice xylan, xylose and oat spelt xylan (Additional file 2: Supplementary Fig. 2). According to substrate specificity, the purified cellulase had high specificity on $\mathrm{CMC}$ which indicated it to be an endo- $\beta$-1,4-glucanase.

\section{Discussion}

The cellulytic activities of the isolated bacterial strains depend on the sources and amount of biowaste in natural environments [24]. In present study, the isolated strains were characterized by morphological and biochemical analysis [19] and then screened for their cellulase activity by Congo red iodine solution and DNS test [21, 25]. The isolated strains were identified as Paenibacillus sp., Bacillus sp. and Aeromonas sp., respectively. The strains were inoculated in fermentation medium and cellulase production was assayed $[19,26]$. Enzyme production by the selected strains was tested with different culture conditions $[27,28]$.

In present study, Paenibacillus sp. had maximum cellulase activity at $\mathrm{pH} 7.0$ and $40{ }^{\circ} \mathrm{C}$ temperature on $24 \mathrm{~h}$ incubation period at $1 \% \mathrm{CMC}$ substrate concentration (Fig. 1 and Additional file 2: Supplementary Fig. 2). In a previous study, the purified cellulase from Paenibacillus sp. E2 and E4 in paper mill sludges showed high enzymatic activity on CMC substrate and filter paper degradation [29].

To characterize the purified enzyme specificity, we initially use qualitative tests like CMC test and filter paper degradation test. CMC agar allows us to identify isolates with cellulase activity on soluble cellulose such as CMC thus representing mainly endoglucanase and beta- glucosidase activities. Secondly, we then screened isolates displaying cellulase activity on CMC for activity on crystalline insoluble cellulose such as filter paper (Additional file 1: Supplementary Fig. 1). In other tests, the purified enzyme showed high activity to CMC and 

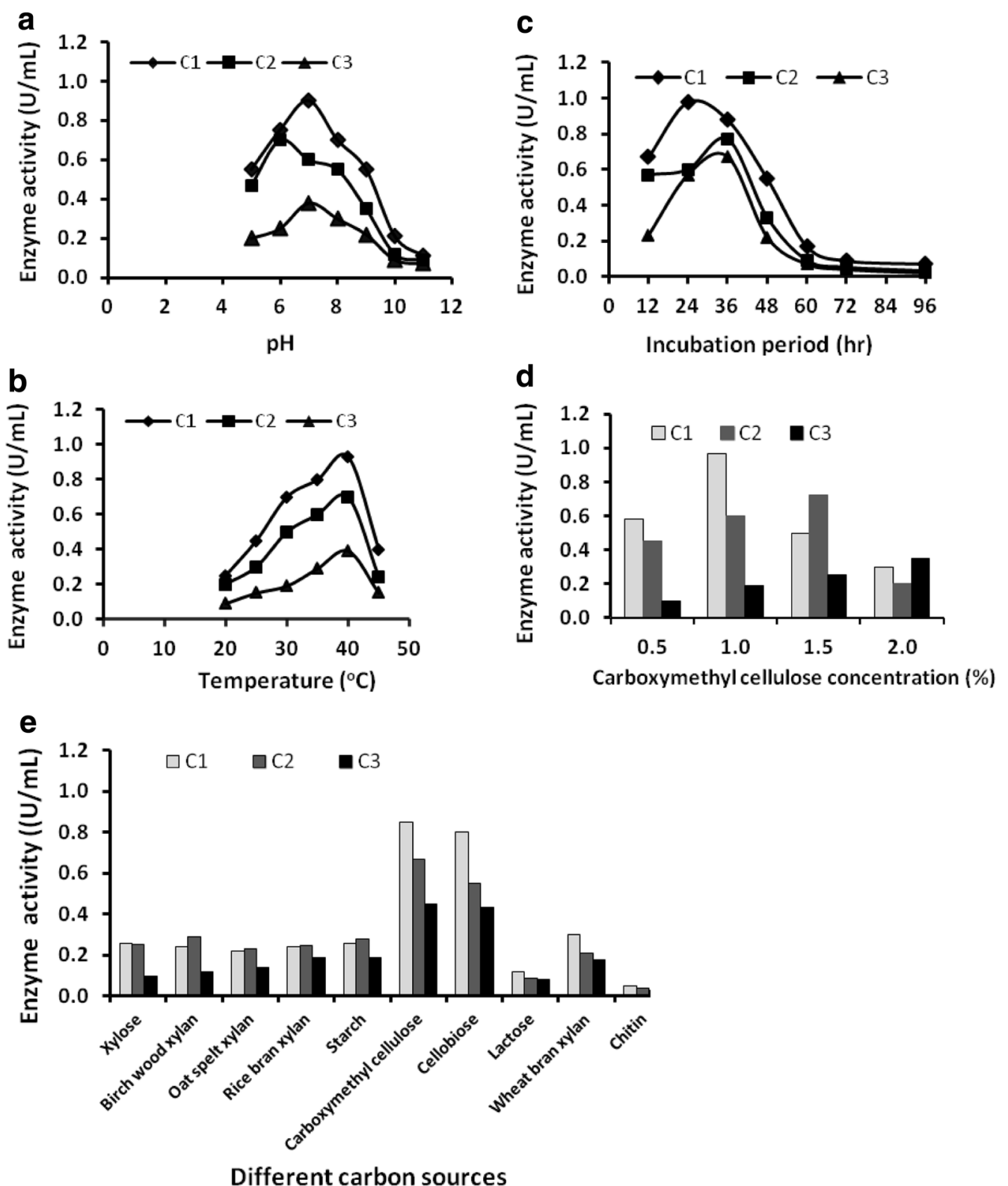

Fig. 1 Optimization of cultural parameters and enzyme activity: a effect of $\mathrm{pH}, \mathbf{b}$ effect of temperature, $\mathbf{c}$ effect of incubation period, $\mathbf{d}$ effect of substrate concentration and $\mathbf{e}$ effect of carbon sources on cellulase production

Table 1 Purification of cellulase from crude sample of Paenibacillus sp.

\begin{tabular}{lllllll}
\hline Purification steps & Volume $(\mathbf{m l})$ & $\begin{array}{l}\text { Total } \\
\text { protein }(\mathbf{m g})\end{array}$ & $\begin{array}{l}\text { Total activity (U) } \\
\text { Crude extract }\end{array}$ & $\begin{array}{l}\text { Specific } \\
\text { activity (U/mg) }\end{array}$ & $\begin{array}{l}\text { Yield (\%) } \\
\text { Purification } \\
\text { fold }\end{array}$ \\
\hline 80\% ammonium sulfate saturation & 1500 & 300 & 81,788 & 273 & 100 & 1 \\
DEAE-cellulose column chromatography & 50 & 160 & 75,121 & 469 & 91.8 & 1.7 \\
CM-cellulose column chromatography & 25 & 40 & 64,525 & 1613 & 78.9 & 5.9 \\
\hline
\end{tabular}




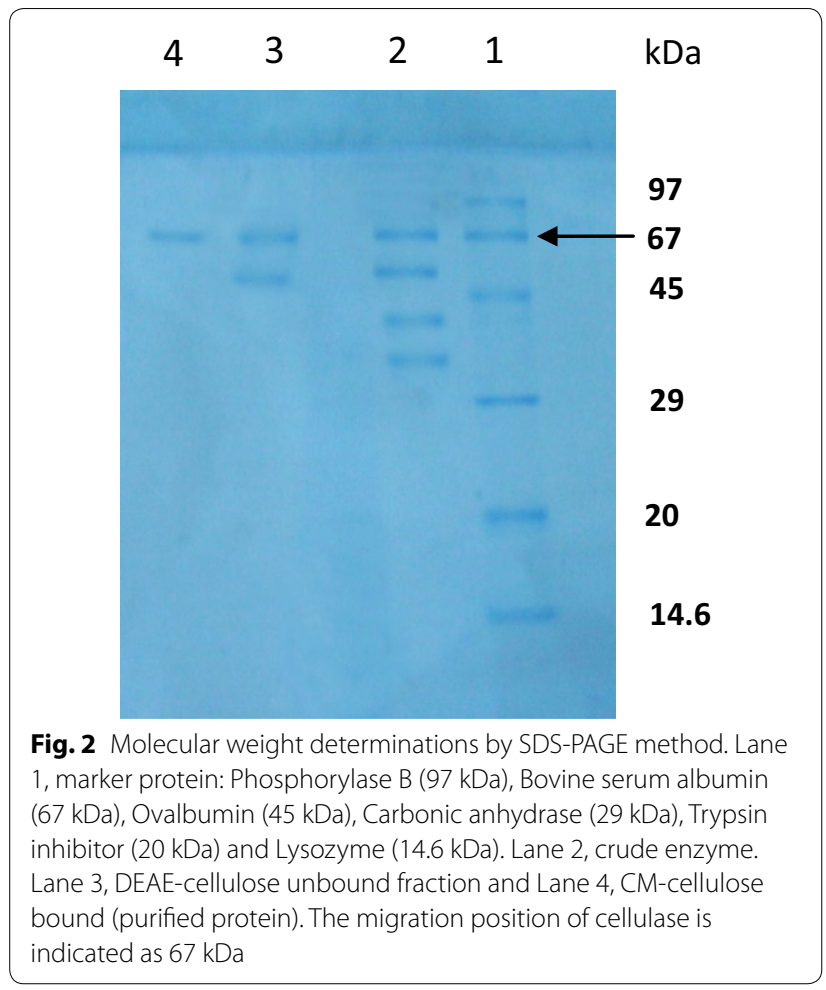

lower activity on xylose, rice xylan and wheat bran xylan (Additional file 2: Supplementary Fig. 2). The high activity on CMC suggests that the CM Case purified from Paenibacillus sp. might be an endoglucanase on the basis of definition by Coughlan and Mayer [30]. Thus, in present study, substrate specificity indicates that the purified enzyme might be an endo- $\beta-1,4$ glucanase. Researchers have also characterized a novel endoglucanase (Cel9P) based on CMC substrate specificity from a newly isolated Paenibacillus sp. BME-14 [31] and a novel thermophilic, cellulose-degrading bacterium Paenibacillus sp. strain B39 from poultry manure compost [32].

Considering highest cellulase activity, Paenibacillus sp. strain was selected for enzyme purification, molecular weight determination and enzyme characterization [33]. In the last stage of enzyme purification, the specific activity, yield and purification fold were $2655 \mathrm{U} / \mathrm{mg}, 35.7 \%$ and 9.7, respectively (Table 1 ). The molecular weight of the purified protein was $67 \mathrm{kDa}$ (Fig. 2) and the enzyme was characterized at $\mathrm{pH} 7.0$ and $40{ }^{\circ} \mathrm{C}$ temperature against different substrates. Among different substrates, CMC was found as a prominent source for maximum endoglucanase production and at optimized conditions the purified enzyme was stable and didn't lose the activity. In present study, all the cellulase positive isolated strain may be an integral part of our future work to develop an efficient cellulase producing systems which can be used for industrial purposes.

\section{Conclusion}

Results of this study indicate that cellulase producing bacterial strains can be grown at different optimized conditions. The isolated strain Paenibacillus sp. showed maximum cellulase activity at $\mathrm{pH} 7.0$ and $40{ }^{\circ} \mathrm{C}$ temperature on $24 \mathrm{~h}$ incubation period at $1 \% \mathrm{CMC}$ substrate concentration. According to substrate specificity, the purified cellulase showed high specificity on CMC which indicated it to be an endo- $\beta$-1,4-glucanase. The purified cellulase might be useful for several industrial applications.

\section{Limitation}

There are two limitations of present study. First, the molasses sample has been collected only from a single sugar industry area and secondly the molecular characterization of the purified cellulose was not performed because of limited lab facilities.

\section{Additional files}

Additional file 1. Supplementary Figure 1: Filter paper degradation by C (control), $C_{1}$, (Paenibacillus sp.), $C_{2}$ (Bacillus sp.) and $C_{3}$ (Aeromonas sp.) strains respectively.

Additional file 2. Supplementary Figure 2: Characterization of cellulase from Paenibacillus sp.: Effect of $\mathrm{pH}(\mathrm{A})$, Effect of temperature (B) and Effect of different substrate (C) on enzyme activity.

Additional file 3. Supplementary Table 1: Physiological and biochemical characteristics of the isolated bacterial strains.

\section{Abbreviations}

CMC: carboxymethyl cellulose; LB: Luria-Bertani; DNS: 3,5-dinitrosalicylic acid.

\section{Authors' contributions}

Fl: conceptualization, data analysis, methodology, manuscript writing. NR: conceptualization, data interpretation, supervision, and critical revision of the manuscript. All authors read and approved the final manuscript.

\section{Author details}

${ }^{1}$ Department of Biochemistry and Molecular Biology, University of Rajshahi, Rajshahi 6205, Bangladesh. ${ }^{2}$ Department of Biochemistry and Molecular Biology, Bangabandu Sheikh Mujibur Rahman Science and Technology University, Gopalganj 8100, Bangladesh.

\section{Acknowledgements}

The authors wish to thank the people who helped in sampling from the sugar industry areas. We also acknowledge some of the MS students and colleagues from our department for their support to complete the study successfully.

This work was supported by a National Science and Technology Fellowship to Farjana Islam and an internal grant from the department.

\section{Competing interests}

The authors declare that they have no competing interests.

\section{Availability of data and materials}

Data related to the tables, graph and calculation are available from the corresponding author upon request. 


\section{Consent to publish \\ Not applicable.}

\section{Ethics approval and consent to participate}

Not applicable

\section{Funding}

No external funding was available for the study.

\section{Publisher's Note}

Springer Nature remains neutral with regard to jurisdictional claims in published maps and institutional affiliations.

\section{Received: 29 May 2018 Accepted: 29 June 2018}

Published online: 04 July 2018

\section{References}

1. Romeo T. Bacterial biofilms. Berlin: Springer; 2008. p. 258-63. ISBN 978-3-540-75418-3.

2. Saha S, Roy R, Sen SK, Ray AK. Characterization of cellulase-producing bacteria from the digestive tract of tilapia, Oreochromis mossambica (Peters) and grass carp, Ctenopharyngodon idella (Valenciennes). Aquac Res. 2006;37:380-8.

3. Klemm D, Heublein B, Fink H-P, Bohn A. Cellulose: fascinating biopolymer and sustainable raw material. Angew Chem Int Ed. 2005;44:3358-93.

4. Bhat MK. Cellulases and related enzymes in biotechnology. Adv Biotechnol. 2000;1:355-83.

5. Shanmugapriya K, Saravana PS, Krishnapriya MM, Mythili A, Joseph S. Isolation, screening and partial purification of cellulose from cellulose producing bacteria. Int J Adv Biotechnol Res. 2012;3:509-14.

6. Immanuel G, Dhanusha R, Prema P, Palavesam A. Effect of different growth parameters on endoglucanase enzyme activity by bacteria isolated from coir retting effluents of estuarine environment. Int J Environ Sci Technol. 2006;3:25-34

7. Perez J, Munoz-Dorado J, de la Rubia T, Martinez J. Biodegradation and biological treatments of cellulose, hemicellulose and lignin: an overview. Int Microbiol. 2002;5:53-63.

8. Gyalai-Korpos M, Nagy G, Mareczky Z, Schuster A, Réczey K, Schmoll M. Relevance of the light signaling machinery for cellulase expression in Trichoderma reesei (Hypocrea jecorina). BMC Res Notes. 2010;7(3):330.

9. Abdelnasser SSI, Ahmed IE. Isolation and identification of new cellulases producing thermophilic bacteria from an Egyptian hot spring and some properties of the crude enzyme. Aust J Basic Appl Sci. 2007;1:473-8.

10. Chandara SKR, Snishamol C, Prabhu NG. Cellulase production by native bacteria using water hyacinth as substrate under solid state fermentation: Malaysian. J Microbiol. 2005;1:25-9.

11. Cavaco-Paulo A. Mechanism of cellulose action in textile processes. Carbohydr Polym. 1998;37:273-7.

12. Cherry JR, Fidantsef AL. Directed evolution of industrial enzymes: an update. Curr Opin Biotechnol. 2003;14:438-43.

13. Nakamura K, Kappamura K. Isolation and identification of crystalline cellulose hydrolyzing bacterium and its enzymatic properties. J Ferment Technol. 1982;60:343-8.

14. Doi RH. Cellulase of mesophilic microbes: cellulosome and non-cellulosome producers. Ann NY Acad Sci. 2008;1125:267-79.

15. Rasul F, Afroz A, Rashid U, Mehmood S, Sughra K, Zeeshan N. Screening and characterization of cellulase producing bacteria from soil and waste (molasses) of sugar industry. Int J Biosci. 2015. https://doi.org/10.12692/ ijb/6.3.230-238.
16. Yin LJ, Huang PS, Lin HH. Isolation of cellulase producing bacteria and characterization of the cellulase from the isolated bacterium Cellulomonas sp. YJ5. J Agric Food Chem. 2010;58:9833-7.

17. Ando T, Chambost JP, Kotoujansky A, Cattano J, Barras F. Mutants of Erwiniachrysanthemi defective in secretion of pectinase and cellulase. $J$ Bacteriol. 1984;160:1199-203.

18. Hong JH, Kim JY, Hur SH. Purification and characterization of an alkaline cellulase from a newly isolated alkalophilic Bacillus sp. HSH-810. Biotech Lett. 2005;27:313-6.

19. Apun K, Jong BC, Salleh MA. Screening and isolation of a cellulolytic and amylolytic Bacillus sp. from pith waste. J Gen Appl Microbes. 2000:46:263-7.

20. Buchanan RE, Gibbons NE. Bergey's of determinative bacteriology. New York: United States of America; 1974. p. 529-63.

21. Miller GL. Use of Dinitrosalisylic acid reagent for determination of reducing sugars. Anal Chem. 1959;31:426-8.

22. Lowry OH, Rosebrough NJ, Farr AL, Randall RJ. Protein measurement with the Folinciocalteu's reagent. J Biol Chem. 1951:193:265-75.

23. Haung XP, Monk C. Purification and characterization of a cellulase from a newly isolated thermophilic aerobic bacterium Caldibacillus cellulovorans gen. nov. sp. World J Microbiol Biotechnol. 2004;20:85-92.

24. Gopinath SM, Shareef I, Ashalatha Ranjit S. Isolation, screening and purification of cellulase from cellulase producing Klebsiella variicola RBER3 (KF036184.1). Int J Sci Res. 2012;3:2319-7064.

25. Irfan M, Safdar A, Syed Q, Nadeem M. Isolation and screening of cellulolytic bacteria from soil and optimization of cellulase production and activity. Turk J Biochem. 2012;37:287-93.

26. Chundakkadu K. Production of bacterial cellulases by solid state fermentation of banana wastes. Bioresour Technol. 1998:69:231-9.

27. Nandimath AP, Kharat KR, Gupta SG, Kharat AS. Optimization of cellulase production for Bacillus sp. and Pseudomonas sp. soil isolates. Afr J Microbiol Res. 2016;10:410-9.

28. Lynd LR, Weimer PJ, van ZyI WH, Pretorius IS. Microbial cellulose utilization: fundamentals \& biotechnology. Microbiol Mol Biol Rev. 2002;66:506-77.

29. Maki ML, Broere M, Leung KT, Qin W. Characterization of some efficient cellulase producing bacteria isolated from paper mill sludges and organic fertilizers. Int J Biochem Mol Biol. 2011:2(2):146-54.

30. Coughlan MP, Mayer F. The cellulose-decomposing bacteria and their enzyme systems. In: Balows A, Truper HG, Dworkin M, Harder W, Schleifer KH, editors. The prokaryotes, vol. 1. New York: Springer; 1992. p. 460-516. ISBN 0-38797258-7.

31. Fu X, Liu P, Lin L, Hong Y, Huang X, Meng X, Liu Z. A novel endoglucanase (Cel9P) from a marine bacterium Paenibacillus sp. BME-14. Appl Biochem Biotechnol. 2010;160:1627-36.

32. Wang CM, Shyu CL, Ho SP, Chiou SH. Characterization of a novel thermophilic, cellulose-degrading bacterium Paenibacillus sp. strain B39. Lett Appl Microbiol. 2008;47(1):46-53.

33. Lee YJ, Kim BK, Lee BH, Jo Kl, Lee NK. Purification and characterization of cellulase produced by Bacillus amyloliquefaciens DL-3 utilizing rice hull. Coll Nat Resour Life Sci. 2006;840:604-714.

Ready to submit your research? Choose BMC and benefit from:

- fast, convenient online submission

- thorough peer review by experienced researchers in your field

- rapid publication on acceptance

- support for research data, including large and complex data types

- gold Open Access which fosters wider collaboration and increased citations

- maximum visibility for your research: over 100M website views per year

At BMC, research is always in progress.

Learn more biomedcentral.com/submissions 